\title{
Rethinking Organic Residues: The Potential of Biomass in Brazil
}

\author{
Aline Rodrigues and Agnieszka Latawiec* \\ Pontifical Catholic University of Rio de Janeiro, Department of Geography and Environment, R. Marquês de São Vicente, 225 - Gávea, Rio de Janeiro - RJ, \\ 22451-000, Brazil.
}

International Institute for Sustainability, Estrada Dona Castorina 124, Rio de Janeiro, Brazil

*Corresponding author: Agnieszka Latawiec, Agricultural University of Kraków, Europe

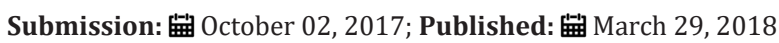

\section{Introduction}

Since the 1970s, the complex relationship between people and nature has been gaining prominence in the world forums related to global environmental changes. The consequences of landscape transformation worldwide have been increasingly recognized not only by the scientific community, but also by the general population. As the world population continues to grow, there is an increasing pressure on water and land to provide an adequate supply of food and industrial products. Projections indicate that by 2030 the population will be 8.5 billion of inhabitants and in 2050 of 9.7 billion [1]. Lack of successful solutions for the conservation of ecosystems and adequate destination for the waste may lead to serious environmental and socio-economic consequences.

One of the biggest challenges today is maintaining industrial production without compromising environmental quality, here referred to as the conservation of natural and human resources. Agriculture and intensive industrial production, which since the middle of the 17th century with the 1st Industrial Revolution has been gaining new forms, needs to be rethought. These processes attend the demand of part of the population with food and products. However, do not solve the problem of the enormous availability of waste derived from these activities. Together with the exploitation of resources, pollution is one of the biggest challenges nowadays. For example, Asian countries outperformed in the 1990s the nitrogen oxide emissions of North American and European countries and this trends continue, representing [2], a race against time for environmental conservation.

Several scientific initiatives have emerged with the aim of creating new uses for waste. For instance, the use of residues such as microalgae for biodiesel production [3], biomass for energy production [4], agricultural residues and municipal solid residues for biogas production [5], use of organic waste for composting and vermicomposting [6], and use of woody, agricultural, urban and industrial pyrolyzed residues to improve soil conditions $[7,8,9]$. Waste is increasingly being perceived by farmers and industries as an input for their businesses, as well as being included in a system with reduced environmental impacts. Brazil is a country with large amounts of residual biomass derived from extensive forest and industrial areas.

This biomass represents a future potential for replacing the production of energy derived from fossil fuels, such as oil and coal, by cleaner mechanisms. The use of residual biomass in agriculture as a source of renewable energy represents an opportunity to reduce environmental problems such as degradation of natural resources, pollution and forest fires. This paper reviews literature related to the use of environmental residues in Brazil. An important point in relation to this issue is to emphasize that biomass should not be withdrawn from its natural source for these processes, but used only when it obtains the character of waste.

\section{Agriculture in Brazil}

The 1950s Green Revolution that contributed to tripling in volume and productivity of food worldwide through the adoption of technological package (machinery, selected seeds, fertilizers, pesticides and irrigation), in Brazil began between the 60s and 70s. The adoption of the technological package had its first incentive in the government of Castelo Branco (1964-1966) with the Government's Economic Action Plan, which sought to boost the agricultural sector by expanding its production of food and raw material, increased exports and substituting imports, incentives to mechanization, among others [10].

The creation of these projects and the others that were created over the years boosted a new socioeconomic and spatial configuration in the country with the hegemony of agro industrial complexes. It was at that moment that there was a great incentive of the state in research to increase agricultural productivity through universities and EMBRAPA (Empresa Brasileira de Pesquisa Agropecuária) in 1973.

The Cerrado biome was the first in the country to receive the technological package, culminating in the expansion of agricultural activity mainly in the cultivation of grains [11]. During this period, the development of new technologies allowed the transformation of the infertile soils once considered unsuitable for agriculture in extremely productive lands [12]. 
Over the years, the expansion of the agricultural frontier has surpassed the limits of the Cerrado towards the Amazonian biome and new areas have been incorporated in the productive process. Current data indicate that the Cerrado has an area of deforestation of 98 million hectares [13], in a total of 203 million hectares of biome [14]. And the Amazon an area of deforestation of 74 million hectares [15] in a total of 419 million hectares of biome [14] According to the FAO, Brazil compared with other developing countries had the highest rate of deforestation in recent years [16]

\section{Residual Biomass in Brazil and is Role in Energy Production}

With the expansion of the agricultural frontier more wastes are generated. In Brazil, the most significant residues of agriculture, livestock and forestry are: sugarcane bagasse [17], animal waste [18], rice hulls [19] and plant material such as twigs, leaves and wood [20]. The use of these residues for energy production and application in crops represent not only an alternative for better environmental quality, due to the high energy demand and improvement of soil conditions, but also for economic growth. It was in 1975 that the first initiative in the country to substitute energy derived from petroleum for sources less aggressive to the environment emerged. Ethanol, produced through sugarcane bagasse, was a landmark for the emergence of the PRÓ-ALCOOL program [21]. Sugarcane bagasse, by its history is the residue used in greater expressiveness in the country to produce energy. The sugar and alcohol industry has been developing this activity in the mills themselves, since it is a profitable alternative when compared to the possibility of transporting the biomass to a different location for the generation of energy.

Another residue derived from sugar-alcohol production is vinhoto, which has been used to produce biogas [18]. The sector is responsible for supplying the internal and external ethanol market, which had its demand increased by the introduction of flex-fuel cars from the 90's [22]. Thus, it is important to highlight that the sugar and alcohol industry is reinventing itself when using its waste to produce energy. However, it is important to emphasize that the production of sugarcane should not be destined to produce energy, but rather to use its waste for generation. Brazil has also a significant production of animal waste, since the production of animal proteins in the country is growing fast.

The country emits the equivalent of 792.5 thousand tons of methane in environments with anaerobic conditions [18], gas that could be used to produce energy through biodigesters. There are also problems related to the contamination of water courses by these residues, making water unfit for consumption and causing death of aquatic animals. Public policies are therefore needed, highlighting the use of this residue for energy production as it has been developed in small rural properties in the Brazilian northeast [23].

Rice hull and coconut shell play an important role in the Brazilian residue scenario. The country, for example, is considered annually one of the largest rice producers in the world [24]. Coconut has recently been on high demand owing to its health benefits [25]. Coconut cultivation has been stimulated and introduced in several regions of the country, and its greatest productions are in the littoral range, favored by the tropical conditions of these regions. There are also new pathways for the use of forestry residues such as the use of urban pruning, construction waste, waste packaging and discards and waste from wood industries.

The use of these materials for energy purposes occurs through the pyrolysis of this material, direct combustion and incineration, gasification and briquetting [26]. The potential for biomass energy generation in Brazil is large, representing an alternative mainly in rural areas with restricted or no access to energy. Its use has advantages because it may contribute to lowering energy production costs, does not require skilled labor, generates employment, and may help combating rural exodus through introduction of novel approach [27]. And just as the sugar and alcohol industry, the paper and cellulose production sector presents good prospects to produce electricity; therefore, incentives for the use of these residual biomasses should be better planned.

From the data presented, it is known that Brazil has a great availability of residues derived from its agropastoril and forestry activities, which are of great relevance for the country's economy. Table presents data on the quantity of residue in the largest amount in the country. Although the energy derived from sugarcane bagasse is the most developed in Brazil, this is not the residue with greater availability (Table 1). The largest residue in Brazil is the animal waste, for example cattle, poultry or swine. The forestry residues it is part of the third residue in greater availability, followed by rice hulls and coconut shells.

Table 1: Information on Brazil's main residues.

\begin{tabular}{|c|c|}
\hline Biomass & Residue production $(\mathbf{t})$ \\
\hline Sugarcane bagasse & 748.636 .167 \\
\hline Animal residues & 1.703 .733 .970 \\
\hline Rice husk & 12.301 .201 \\
\hline Coconut shell & 1.790 .739 \\
\hline Forestry residues & 30.000 .000 \\
\hline
\end{tabular}

This characteristic is related to the location of the country in the tropical and subtropical strip, considered the best zone of the world to produce biomass. Thus, given the incentives and recognition of the need to change the energy matrix in the world, Brazil has a privileged role for the development of research and technology for the use of residue in energy production. In 2010, the first biogas laboratory was installed in the country, in the Itaipu technological park, aiming to promote technological development to produce energy derived from plants and animal waste [18].

\section{Residual Biomass and its Role in the Soil}

Intentional use of biomass residues in soils in the world is not a recent invention. The application of carbonized waste material 
in soils in Japan is a millenarian practice and its use in crops is a past knowledge [28]. In Brazil, the Amazonian Dark Earths (ADE), with the presence of carbonized residual material, giving peculiar characteristics to these soils. The ADE are soils of pre-Columbian origin, with contrasting characteristics when compared to the soils of the Amazon region in general weathered. It presents a high degree of resilience and fertility [29], and for these attributes has been motivating researches for further exploration of this phenomena.

Several research point out that these attributes are related to the presence of carbonized residues that, in interaction with microorganisms, enzymes, fauna and chemical reactions, formed a material of high value. The presence of this carbonized material provided bases for the search for New Black Earth [30]. Biochar is a product that seeks to imitate the characteristics of the carbonized material present in the $\mathrm{ADE}$. It is produced by pyrolysis of residual forest biomass such as tree pruning and agro pastoral waste biomass such as sugarcane bagasse, crop residues, manure, among others. In this process, in addition to the production of biochar there is the production of bio-oil and biogas, fuels that can replace oil.

Residual biomass transformed into biochar has a high capacity to store its carbon, as it is more resistant to degradation by microorganisms when compared to the original material. A product with such characteristics can add value to the waste, both by creating an innovative use for a traditional product, and by being the object of raising funds derived from practices in line with the Clean Development Mechanism concept, once considered its capacity to carbon transfer from the atmosphere to a stable compartment, which is the soil organic matter [31]. The application of biochar of eucalyptus in an experiment with rice, resulted in increase of this food in the second cycle [7] and the application of biochar with poultry manure increases the yield of maize in the Amazon region [8]. In the forest restoration studies with seedlings of Brazil nut, the species native to the Amazon basin, have suggested that substrates with $30 \%$ and $50 \%$ of biochar derived for wood had higher seedling growth relative to the growth of seedlings grown in forest soils [32]

Other case studies with seedlings of Tachigali vulgaris (carvoeiro), a species native to the Cerrado, show that biochar from eucalyptus applied in concentrations of $12.5 \%, 25 \%$ and $50 \%$ had a significant effect on the development of the seedlings, and the concentration of $50 \%$ resulted in the healthiest leaves during the dry season [33]. Composting and vermicomposting are also methods that use residue for the formation of fertilizer Both processes can occur in the rural and domestic environment which promotes diversification of uses for organic waste. These two processes comprise a low cost technological system for the transformation of organic residues into compounds that may have high nutritional value for plants [34].

Soil is a natural resource of great importance for the growth and maintenance of forests, regulating the hydrological and biogeochemical cycles, as well as the great supplier of food. The use of residues in soils, are efficient to improve their conditions as cited in the studies above, and may replace the Green Revolution system that are more aggressive to the soil resource. Mechanized and high fertilizer use of agrochemicals in the world has become a major threat to soils resulting in erosion, desertification and destruction of plant cover. Brazil is the largest consumer of pesticides in the world [35], and the toxicity risk class of pesticides indicate only the degree of hazard of a product and do not define exactly what the risks are [36].

Government oversight is weak, outdated legislation and tax dispensation ensures that the country continues to lead the ranking in a position that expos serious health risks to the population. For progress to be made regarding soil conservation in the world and in Brazil, it is necessary for the executive, legislative and judicial powers dialogue with scientists and civil society for decisionmaking, so as not to approve measures that are going towards contrary sustainable standards. The use of residues for application in agriculture, such as the use of biochar and methods such as composting and vermicomposting, have been presented as viable alternatives to reduce environmental damage, so more investments in research happen over the next years.

\section{Final Considerations}

Residues and its transformation into energy is an ally to the development of countries, because it generates an alternative source of energy production. As supply of energy rises, the price decreases. Energy derived from biomass generates not only environmental and economic benefits but also social, as energy production in poor rural environments, which encourages new attractive rural activities. In agriculture, the use of waste is ancient wisdom, emphasizing the importance of knowledge of the so-called traditional populations. The New Black Earth, with the presence of biochar, symbolizes new forms of mitigation of the current environmental problems. The development of this soil conditioner with characteristics like the carbonized product found in the ADE makes this product investigated, one of the few capable of improving soil degradation, in some cases improving food production and reducing greenhouse gases, in a single combination. Symbolizing an important step in the change of conventional agro pastoral production systems, which has destroyed natural resources.

The analysis of the use of waste for energy production and use in agriculture are of fundamental importance. It is necessary to focus on residual biomass management because the problem of waste has been related to the destruction of forests, soil pollution, water, air and public health globally. Much of these wastes are not treated properly and are intended for open-pit dumps $[37,38]$. Therefore, government, universities, research institutions and society must unite for more sustainable use of organic wastes in Brazil and worldwide.

\section{References}

1. Department of Economic and Social Affairs, Population Division (2015) World Population Prospects: The 2015 Revision, Key Findings and Advance Tables. United Nations, p: 241 
2. Akimoto H (2003) Global air quality and pollution. Science 302(5651): 1716-1719.

3. Dasgupta NC, Suseela MR, Mandotra SK, Kumar P, Pandey MK, et al. (2015) Dual uses of microalgal biomass: An integrative approach for bio hydrogen and biodiesel production. Applied Energy 146.

4. Ericsson K, Werner S (2016) The introduction and expansion of biomass use in Swedish district heating systems. Biomass and Bioenergy 94: 5765.

5. Al Hamamre Z, Saidan M, Saidan M, Hararah M, Rawajfeh K (2017) Wastes and biomass materials as sustainable-renewable energy resources for Jordan. Renewable and Sustainable Energy Reviews 67: 295-314.

6. Ansari AA (2008) Effect of Vermicompost on the Productivity of Potato (Solanum tuberosum), Spinach (Spinaciaoleracea) and Turnip (Brassica campestris). World Journalof Agricultural Sciences 4(3): 333-336.

7. Petter FA, Madari BE, Silva MAS, Carneiro MAC, Carvalho TMC (2012) Fertilidade do solo e produtividade do arroz de terras altas no Cerrado após aplicação de biochar. Pesq. Agro pec. Bras 47(5): 699-706.

8. Steiner C, Teixeira WG, Lehmann J, Nehls T, Macedo JJV, et al. (2007) Long term effects of manure, charcoal and mineral fertilization on crop production and fertility on a highly weathered Central Amazonian upland soil. Plant and Soil 291: 275-290.

9. Yuan H, Lu T, Wang Y, Chen Y, Lei T (2016) Sewage sludge biochar: Nutrient composition and its effect on the leaching of soil nutrients. Geoderma 267: 17-23.

10. Yuan H, Lu T, Wang Y, Chen Y, Lei T (2016) Sewage sludge biochar: Nutrient composition and its effect on the leaching of soil nutrients. Geoderma 267: 17-23.

11. Pires M (2000) Programas agrícolas na ocupação do Cerrado. Sociedade e Cultura 3(1,2): 111-131.

12. Ribeiro EM, Galizoni FM (2005) Expansão da agropecuária e terras comuns: quatro casos nos Cerrados de Minas Gerais. In: Anais do XLII Congresso Brasileiro de Economia e Sociologia Rural (SOBER), Ribeirão Preto, p: 19.

13. Santos MA, Barbieri AF, Guedes GR, Machado CJ, Carvalho JAM (2012) Dinamica demográfica e o uso da terra no Cerrado brasileiro: reflexões a partir da experiência do Padap. Rev Econ Sociol Rural, 50(2).

14. MMA (2011) Monitoramento do bioma Cerrado 2009-2010, Projeto Monitoramento do desmatamento nos biomas brasileiros por satélite, Ministério do Meio Ambiente (MMA) Brasília, Brazil.

15. IBGE (2004) Instituto Brasileiro de Geografia e Estatística. Mapa de biomas do Brasil. Rio de Janeiro RJ, Brazil.

16. PPCD Am (2013) Plano de ação para prevenção e controle do desmatamento na Amazônia legal. 3a Fase (2012-2015) pelo Uso Sustentável e Conservação da Floresta.

17. Houghton RA (2005) Tropical deforestation as a source of greenhouse gases. In: Tropical Deforestation and Climate Change Moutinho $P$ Schwartzman S (Eds), Instituto de Pesquisa Ambiental da Amazônia (IPAM)e Environmental Defense (ED), USA.

18. Bley C, Libânio JC, Galinkin M, Oliveira MM (2009) Agroenergiada biomassa residual: perspectivas energéticas, socioeconômicas e Ambientais. (2 ${ }^{\mathrm{a}}$ edn) Foz do Iguaçu/Brasília, Itaipu Binacional, Organização das Nações. Unidas para Agricultura e Alimentação, Techno Politik, Brazil, p: 140

19. Hoffman R (1999) Método Avaliativo da Geração Regionalizada de Energia, em potências inferiores a $1 \mathrm{MW}$ a partir da gestão de resíduos de Biomassa-0 caso da Casca de Arroz. Dissertação de Doutorado, PROMECUFRGS, Porto Alegre.
20. Soares TS, Carneiro AC, Gonçalvez EO, Lelles JG (2006) Uso da biomassa florestal na geração de energia. Revista cientifica eletrônica de engenharia florestal. Ano Agosto de 4(8)

21. Shikida PFA, Perosa BB (2012) Alcool combustível no Brasil e path dependence. Rev Econ Sociol Rural 50(2).

22. Pires A, Schechtman R (2009) No mundo, incentivos fiscais e cotas na matriz estimulam uso de biocombustíveis. In: Etanol e Bioletricidade-A cana-de-açúcar no futuro da matriz energética. Eduardo L, Souza e Isaias C, Macedo, São Paulo (Eds).

23. Mattos LC, Farias M (2011) Manual do biodigestor sertanejo. Recife: Projeto Dom Helder Camara.

24. FAO (2014) Rice Market monitor. Food Agriculture Organization of the United Nations 18(4)

25. Bitti MT, Perazzini H, Silveiro RJR (2009) Avaliação preliminar do aproveitamento da casca de coco verde para a co-geração de energia: um estudo de caso. VIII Congresso Brasileiro de Engenharia Química em Iniciação Científica julho de, Uberlândia, Minas Gerais, Brasil, 27(30).

26. MMA (2009) Aproveitamento de resíduos e subprodutos florestais, alternativas tecnológicas e propostas de políticas ao uso de resíduos florestais para fins energéticos, Projeto PNUD BRA 00/20-Apoio às Políticas Públicas na Área de Gestão e Controle Ambiental, Ministério do Meio Ambiente (MMA) Brasília, DF 2(40): 1-40.

27. Soares TS, Carneiro AC, Gonçalvez EO, Lelles JG (2006) Uso da biomassa florestal na geração de energia. Revista cientifica eletrônica de engenharia florestal. Ano Agosto de 4(8).

28. Ogawa M, Okimori Y (2010) Pioneering works in biochar research. Japan, Soil Research 48(7): 489-500.

29. Novotny EH, Hayes MHB, Madari BE, Bonagamba TJ, de Azevedo ER, et al. (2009) Lessons from the Terra Preta de Índios of the Amazon region for the utilization of charcoal for soil amendment. Braz Chem Soc 20(6).

30. Lehmann J (2009) Terra Preta Nova-Where to from here? In: Woods WI, Teixeira WG, Lehmann J, Steiner C, Winkler Prins A, et al. (Eds.), Amazonian Dark Earths: Wim Sombroek's Vision, L. Springer.

31. Benites VM, Teixeira WG, Rezende ME, Pimenta AS (2009) Utilização de carvão e subprodutos da carbonização vegetal na agricultura: aprendendo com as Terras Pretas de Índio. In: Teixeira WG, Kern DC, Madari BE, Lima HN, Woods WI (Eds), As Terras Pretas de Índio da Amazônia: sua caracterização e uso deste conhecimento na criação de novas áreas. Manaus: Embrapa Amazônia Ocidental, p: 285-296.

32. Nunes MM, Teixeira WG (2010) Crescimento de mudas de castanheira-do Brasil (Bertholletia excelsa HBK) em função de doses de carvão vegetal componentes de substrato. In: Reunião Cientifica da rede CTPETRO Amazonia, 3, 2010, Manaus. Manaus: Petro Amazônia.

33. Souchie FF, Marimon BH, Petter FA, Madari BE, Marimon BS, et al. (2011) Carvão pirogênico como condicionante para substrato de mudas de Tachigalivulgaris L.G. Silva \& H.C. Lima. Ciência Florestal 21(4): 811-821.

34. Hand P, Hayes WA, Frankland JC, Satchell JE (1998) Vermi composting of cow slurry. Pedobiologia 31(3): 199-209.

35. Londres F (2010) Agrotóxicos no Brasil: um guia para a ação e defesa da vida. Rio de Janeiro: AS-PTA. Assessoria e serviços a projetos em agricultura alternative.

36. Garrido LR, Sônego OR (2003) Uvas viníferas para processamento em regiões de clima temperado. Versão Eletrônica. Bento Gonçalves: Embrapa Uva e Vinho. 
Creative Commons Attribution 4.0 International License

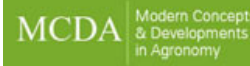

For possible submissions Click Here
Modern Concepts \& Developments in Agronomy

\section{Benefits of Publishing with us}

- High-level peer review and editorial services

- Freely accessible online immediately upon publication

- Authors retain the copyright to their work

- Licensing it under a Creative Commons license

- Visibility through different online platforms 